\title{
A crise na beleza é uma crise ética
}

\section{Mauricio José Melim}

Associação Educacional Luterana Bom Jesus, Joinville, SC, Brasil ORCID: https://orcid.org/0000-0002-1111-1625

HAN, Byung-Chul.

A salvação do belo. Petrópolis: Vozes, 2019.

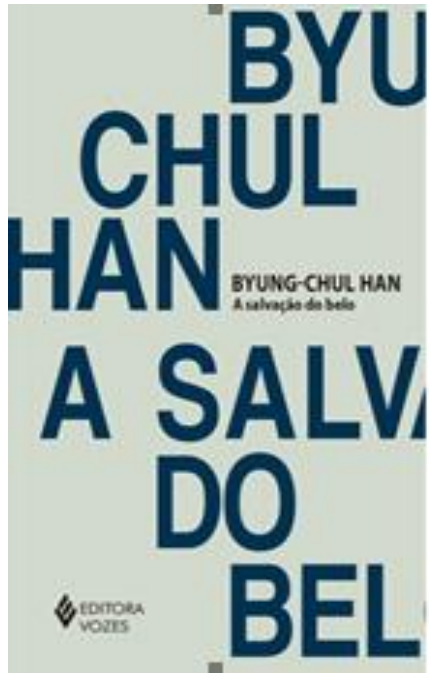

A cultura contemporânea nos coloca próximos demais dos outros, dos objetos e de nós mesmos. Esse regime de proximidade, diz Byung-Chul Han, neutraliza o belo. Han nasceu em Seul, Coreia do Sul, mas vive na Alemanha desde os tempos de faculdade, quando estudou Filosofia, Literatura e Teologia. Hoje, leciona na Universidade de Berlim e tem sido descrito como um dos ensaístas mais interessantes dos últimos anos.

À primeira vista, a afirmação de Han sobre a beleza poderia soar contraditória, pois a beleza parece estar mais presente do que nunca. Dos ambientes offline aos ambientes online, das mercadorias aos nossos corpos, tudo ostenta algum tipo de atrativo estético. Não é dessa beleza comercial que Han está tratando, mas do belo em seu sentido forte e tradicional. A estetização do mundo, que deve muito às formas atuais do capitalismo, instaurou uma ordem sensível que destrói a possibilidade de emergência do belo, que requer, como veremos, tempo e espaço para se manifestar. A estética, entretanto, representa apenas uma parcela do que foi e continua sendo abalado pelo capitalismo. 0 fim do belo, diz 
Han, não é só um problema estético, é também um problema para o convívio e a vinculação com o outro.

"A salvação do belo" mantém o estilo de outros livros de Han, como "Sociedade do cansaço" (2015), "Sociedade da transparência" (2017) e "No enxame: perspectivas do digital" (2018). Em todos eles há um conjunto de ensaios breves que somam pouco mais de uma centena de páginas. À medida que se avança a leitura desses livros, nota-se que temas e ideias são retomados por novos ângulos, adquirindo assim camadas complementares de sentido. Quem percorrer a bibliografia de Han perceberá que não raro o autor dialoga de forma explícita também com seus livros precedentes.

Em "A salvação do belo", por exemplo, reaparecem noções como a sociedade pornográfica, a velocidade e a aceleração dos fluxos informacionais, todas elas presentes em livros anteriores. Esse processo de retomada e revisão, seja entre os ensaios de um mesmo livro, seja entre livros, leva a imaginar um autor que, por diferentes caminhos e momentos, está tentando aproximar-se cada vez mais de seu objeto. Não há uma sequência rígida entre os ensaios deste livro. 0 leitor que escolhe ler alternadamente cada seção ou começa pelo final do volume, não perde nada em relação ao leitor que opta pelo percurso comum, do início para o fim. Cada ensaio discute um ou mais aspectos da cultura contemporânea por meio do conceito de belo resgatado da tradição estética. Nesse sentido, a relação entre os textos é muito mais de complementariedade do que de submissão ou hierarquia.

Essa constelação proposta por Han leva a uma conclusão mais ou menos esperada, a saber, não há mais espaço para o belo. Esperada, porque o belo, nos moldes tradicionais, exige uma gama de condições subjetivas e sociais impossíveis de serem revividas. Não há dúvida de que hoje exista beleza. Mas isso nada tem a ver com o belo da tradição. 0 interessante, então, não está tanto na conclusão do livro, mas nas observações sobre a cultura contemporânea, que vão surgindo junto dos objetos considerados, como as artes plásticas, as redes sociais, a literatura, o teatro e a subjetividade.

Conforme Han, as formas que hoje constituem o espaço social adquiririam certa "lisura". Nossas produções são lisas, contínuas, velozes, sem aderência nem resistência, sem atrito. Tudo flui, afirma o autor. Vivemos uma sociedade comunicativa em que nada espanta ou causa horror, nada obstaculiza as trocas. 0 liso está presente na arte polida, espelhada e infantil de Jeff Koons (Han se refere aí especificamente à série de esculturas Balloon Dog). 0 liso está presente na depilação à brasileira, que elimina os pelos do entorno genital mantendo tudo visível. Nas imagens pornográficas, porque entregam tudo de imediato 
inviabilizando o erótico. No romance comercial, de linguagem transparente e veloz. No teatro contemporâneo, sem desvios e mistérios, sem espaço para a imaginação. 0 liso está também nas plataformas digitais, onde tudo é veloz e instantâneo, sem nenhuma contemplação.

Na tradição estética resgatada por Han, que inclui Kant, Hegel, Nietzsche e Adorno, o belo é o oposto do liso. 0 belo tem a ver com a fricção e a quebra dos livres fluxos comunicativos. Não resulta em uma compreensão plena e precisa, e sim em uma experiência de ferimento, de abalo do sujeito. 0 belo é da ordem do velamento, não da revelação ou da entrega. Tem a ver com os desvios, as metáforas, as alusões e com seu invólucro. Como disse Han (2019, p. 44), "Belo é o objeto em seu invólucro, em seu velamento, em seu esconderijo.", de modo que o invólucro é, por vezes, mais importante que o próprio objeto. 0 belo pressupõe duração, demora e atraso, não vem de imediato. Não está disponível o tempo todo como os objetos de consumo.

Todos esses aspectos fazem da experiência do belo uma experiência de deslocamento do sujeito, de desinteriorização, diz Han. O belo se manifesta como acontecimento. Algo que tira o sujeito de si e o abre para o outro, para o heterogêneo. Esse abalo é o grande tema do autor. O livro trata de estética, mas enquanto fato da cultura capaz de engendrar um sujeito que escuta, dialoga e encara a alteridade. Nesse aspecto, diz Han, a cultura digital não contribui. Pelo contrário, devido a sua instantaneidade e disposição para oferecer tudo o que se quer, ela instiga o sujeito à interiorização e ao fechamento sobre si mesmo.

A lógica capitalista visa a sintonia entre produção e consumo, e assim exclui tudo aquilo que possa causar embaraços. Nas plataformas digitais, mas também nos espaços offline, toda a negatividade tende a ser eliminada. Não deve haver ruídos, não pode haver demora ou quaisquer obstáculos à acessibilidade. As trocas são então caracterizadas por apelos intensos, sexy e alegres. Trata-se de uma sociedade da positividade e da complacência cujo símbolo é o like. Por essas condições, por encontrar um mundo que o estimula de forma infantil, dando o que deseja instantaneamente, o sujeito tende a ficar ensimesmado e evitar o outro.

Salvar o belo é salvar um regime de sensibilidade que se identifica com a dificuldade e o conflito, um regime que preza a morosidade e aceita a opacidade do outro. Nessa linha, o belo não se restringe a questões de estética, mas se estende, também, a questões do convívio. 0 sujeito configurado na cultura do belo não espera receber tudo o que quer, do 
modo como quer, ele não espera encontrar no outro um reflexo de si mesmo. Esse sujeito está mais aberto à diferença e, assim, convive melhor.

A Escola de Frankfurt já havia denunciado a impossibilidade do belo no interior das sociedades capitalistas. Por que, então, Han retoma esse conceito? Fredric Jameson (1994) nos ensinou que só nos damos conta de nossa cultura quando nos deparamos com outra cultura. Essa talvez seja a razão pela qual Han utilizou o belo como operador. 0 belo, como regime estético distinto do regime atual, ajuda-nos a nomear aquilo em que estamos imersos e, por isso mesmo, não conseguimos constatar facilmente: a presença do liso, a intensidade e velocidade das mudanças, a imediaticidade, a pornografia, a simplicidade das formas.

\section{Referências}

HAN, Byung-Chul. A salvação do belo. Petrópolis: Vozes, 2019.

HAN, Byung-Chul. No enxame: perspectivas do digital. Petrópolis: Vozes, 2018.

HAN, Byung-Chul. Sociedade da transparência. Petrópolis: Vozes, 2017.

HAN, Byung-Chul. Sociedade do cansaço. Petrópolis: Vozes, 2015.

JAMESON, Fredric. Sobre os 'Estudos de Cultura'. Novos Estudos CEBRAP, São Paulo, n. 39, p. 11-48, jul. 1994.

\section{The beauty crisis is an ethical crisis}

\section{Autoria para correspondência}

Maurício José Melim

mauriciomelim@gmail.com

\section{Como citar}

MELIM, Maurício José. A crise da beleza é uma crise ética. Intexto, Porto Alegre, n. 53, e-108602, jan./dez., 2022. DOI: http://dx.doi.org/10.19132/1807-8583202253.108602

Recebido em 22/10/2020

Aceito em 14/10/2021 